\title{
Effect of Oxygen Concentration, Temperature and Combined Nitrogen on the Morphology and Nitrogenase Activity of Rhizobium sp. Strain 32 1 in Agar Culture
}

\author{
By C. E. PANKHURST AND A. S. CRAIG \\ Applied Biochemistry Division, Department of Scientific and Industrial Research, \\ Palmerston North, New Zealand
}

(Received 18 January 1978)

\begin{abstract}
Cultures of Rhizobium sp. strain 32H1 grown in a layer of soft agar on top of a layer of harder agar developed maximum nitrogenase activity [80 to $90 \mathrm{nmol}$ acetylene reduced $\mathrm{h}^{-1}$ (mg protein $)^{-1}$ ] after $12 \mathrm{~d}$ in air at $28^{\circ} \mathrm{C}$. Electron microscopy of sections of cores of the soft agar layer showed differences in the morphology of rhizobia in colonies growing at the surface, in the middle or at the bottom of the layer. The properties of rhizobia growing in the colonies in the middle of the soft agar layer suggested that only these contained nitrogenase. These rhizobia were present as a distinct band of cells passing through individual colonies at a constant depth in the agar. They were larger than normal vegetative Rhizobium, were pleiomorphic and were similar in morphology to the nitrogen-fixing bacteroids formed by strain $32 \mathrm{H} 1$ in cowpea root nodules. Their location within the soft agar layer changed with the $\mathrm{O}_{2}$ concentration in the atmosphere above the agar during growth, and they were not found in cultures showing little or no nitrogenase activity. Loss of nitrogenase activity occurred when cultures were grown at $33^{\circ} \mathrm{C}$, in a $\mathrm{O}_{2} / \mathrm{Ar}(1: 4, \mathrm{v} / \mathrm{v})$ atmosphere, or when the concentration of combined nitrogen in the agar medium was increased from 2 to 20 mM-N.
\end{abstract}

\section{INTRODUCTION}

Several strains of Rhizobium japonicum, Rhizobium sp. ('cowpea-type' rhizobia) (Keister, 1975; Pagan et al., 1975; Kurz \& La Rue, 1975; McComb, Elliott \& Dilworth, 1975) and one strain of $R$. leguminosarum (Kurz \& La Rue, 1975) develop nitrogenase activity when cultured on a defined medium, provided a carboxylic acid and a source of combined nitrogen are present (Gibson et al., 1976). When a cowpea strain of Rhizobium (strain 32H1) is grown in an agitated liquid medium (Keister \& Evans, 1976) or in a chemostat (Bergersen et al., 1976), nitrogenase activity develops if the dissolved oxygen concentration in the medium is below about $1 \mu \mathrm{M}$. However, when strain 32H1 is grown on an agar medium (Gibson et al., 1976) or in a stationary liquid medium (Evans \& Keister, 1976), nitrogenase activity develops even with air as the gas phase above the medium. Gibson et al. (1976) suggested that in these cultures nitrogenase activity is restricted to zones within which the oxygen concentration and/or flux is favourable for the maintenance of continued activity.

In the present report, a method is described for studying the morphology of free-living Rhizobium sp. strain $32 \mathrm{H} 1$ as nitrogenase activity develops during growth in a solid medium. Using this method we have identified rhizobia within the culture which are probably responsible for nitrogen fixation. The effects of oxygen concentration, temperature and combined nitrogen on the development of these rhizobia are described. 


\section{METHODS}

Organism and growth. Rhizobium sp. strain 32H1 was obtained from Dr J. C. Burton, Nitragin Company, Milwaukee, Wisconsin, U.S.A. A working stock culture was established following a single colony isolation and was maintained on a mannitol/salts/yeast extract $\left(\mathrm{M}^{+}\right)$medium (Pankhurst, 1977). This culture could nodulate siratro [Macroptilium atropurpureum (DC.) Urb.] and cowpea [Vigna unguiculata var. Caloona].

The CS8 medium described by Scowcroft, Gibson \& Pagan (1976) was used to establish nitrogenase activity in strain $32 \mathrm{H} 1$ in all experiments. Arabinose, glutamine and vitamins were sterilized separately by filtration through a sintered glass filter $(0 \cdot 3 \mu \mathrm{m}$ pore size) and added to the rest of the medium prior to dispensing $8 \mathrm{ml}$ portions into $28 \mathrm{ml}$ McCartney bottles.

A 10 to 12-d-old culture grown on $\mathrm{M}^{+}$medium was suspended in CS8 broth to give an $\mathrm{A}_{600}$ of 0.40 $\left(\equiv 2 \times 10^{8}\right.$ bacteria $\left.\mathrm{ml}^{-1}\right)$. In all experiments (unless otherwise specified) this suspension was added to $1.0 \%(\mathrm{w} / \mathrm{v})$ agar in CS8 medium kept molten at $45^{\circ} \mathrm{C}$, to produce an inoculum containing $5 \times 10^{7}$ bacteria $\mathrm{ml}^{-1}$ in $0.75 \%$ agar. From this inoculum $0.2 \mathrm{ml}$ was spread over the surface of $1.0 \%$ agar in CS 8 medium in McCartney bottles which, unless otherwise specified, were closed with loose-fitting metal caps and incubated at $28^{\circ} \mathrm{C}$.

Nitrogenase activity. Nitrogenase activity was assayed by acetylene reduction (Hardy et al., 1968). The loose-fitting metal caps of the McCartney bottles were replaced with screw caps containing a central hole ( $3 \mathrm{~mm}$ diam.) and lined with a thick $(2.5 \mathrm{~mm})$ rubber liner. Air $(2 \mathrm{ml})$ was withdrawn from the bottles with a syringe and replaced with $2 \mathrm{ml}(0 \cdot 1 \mathrm{~atm})$ acetylene. The bottles were then incubated for 2 to $3 \mathrm{~h}$ at $28^{\circ} \mathrm{C}$ (unless otherwise specified). Gas samples $(0.2 \mathrm{ml})$ were removed at various times after $30 \mathrm{~min}$ and analysed for their acetylene and ethylene content using a Varian 900 gas chromatograph with a flame ionization detector and a Poropak $\mathrm{T}$ column $(2 \mathrm{~mm} \times 1 \mathrm{~m})$. Acetylene was used as an internal standard. Nitrogenase activities are expressed as nmol acetylene reduced $h^{-1}$. Following each assay the screw caps of the McCartney bottles were replaced with the original loose-fitting metal caps and the bottles were returned to the incubator. After $24 \mathrm{~h}$ no acetylene or ethylene could be detected in the bottles enabling the cultures to be re-assayed at a later date.

Growth and nitrogenase activity in different gas atmospheres. Immediately after inoculation, the McCartney bottles containing the $32 \mathrm{H} 1$ cultures were placed inside large $(50 \times 37.5 \mathrm{~cm})$ plastic bags fitted with inlet and outlet rubber tubes. The required gas mixtures $\left(\mathrm{O}_{2} / \mathrm{N}_{2}\right.$ or $\left.\mathrm{O}_{2} / \mathrm{Ar}\right)$ were then passed through the bags at approximately $10 \mathrm{ml} \mathrm{min}^{-1}$. To measure the nitrogenase activity of the cultures, the bags were allowed to deflate slowly until the loose-fitting metal caps of the McCartney bottles could be replaced with the screw caps. The bottles were then removed from the bags and acetylene was injected into them. When cultures were assayed for nitrogenase activity in atmospheres different from that used for their growth, the bottles were evacuated and brought to atmospheric pressure with the desired gas mixture. Gases were supplied by New Zealand Industrial Gases, Palmerston North, New Zealand. The limits of impurities in these gases were: $\operatorname{Ar}\left(<50\right.$ p.p.m. $\mathrm{N}_{2}$, < 5 p.p.m. $\mathrm{O}_{2},<1$ p.p.m. $\left.\mathrm{H}_{2}\right) ; \mathrm{O}_{2}\left(<0.5 \% \mathrm{Ar},<50\right.$ p.p.m. $\mathrm{H}_{2},<5$ p.p.m. $\left.\mathrm{CO}_{2}\right)$; $\mathrm{N}_{2}$ (< 10 p.p.m. $\mathrm{O}_{2}$, < 5 p.p.m. $\mathrm{CO}_{2}$, < 1 p.p.m. $\mathrm{H}_{2}$ ).

Bacterial protein content. The soft agar layer was removed from the basal agar plug with a spatula and digested in $1.0 \mathrm{M}-\mathrm{NaOH}$ for $10 \mathrm{~min}$ at $100^{\circ} \mathrm{C}$, before bacterial protein was determined by the method of Lowry et al. (1951). Bovine serum albumin (fraction V, Sigma) mixed with sterile $0.75 \%$ CS 8 soft agar was used as the standard.

Microscopy. Core samples of the soft agar layer, together with a small plug of the underlying basal agar, were removed from the agar cultures using a syringe. The syringe was modified so that the plunger could be screwed into the barrel, permitting better control when removing core samples from the agar. The syringe was fitted with a wide-bore needle $(2 \mathrm{~mm}$ diam.) with a squared end. The agar samples were prepared for electron microscopy as described by Craig \& Williamson (1973) and embedded in epoxy resin using butyl rubber moulds. Thick and thin sections were cut vertically through the culture enabling the morphology of the rhizobia growing in colonies near the surface of the soft agar layer and those growing in colonies near the bottom of the agar layer to be studied in single sections. Thick sections ( 2 to $3 \mu \mathrm{m}$ ) were stained with toluidine blue $(0.05 \%, \mathrm{w} / \mathrm{v}$, in $0.1 \mathrm{~m}$-phosphate buffer $\mathrm{pH} 7 \cdot 2)$. Polysaccharides were located using the Alcian blue staining procedure of Behnke \& Zelander (1970).

\section{RESULTS}

\section{Nitrogenase activity in agar culture}

In preliminary experiments, nitrogenase activity was observed in strain $32 \mathrm{H} 1$ after spreading $0.2 \mathrm{ml}$ of a suspension containing about $5 \times 10^{7}$ bacteria $\mathrm{ml}^{-1}$ in CS8 broth on the 


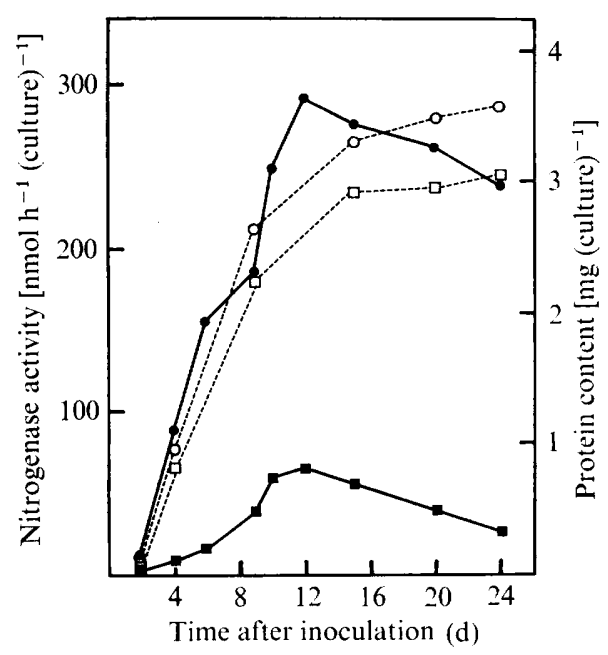

Fig. 1

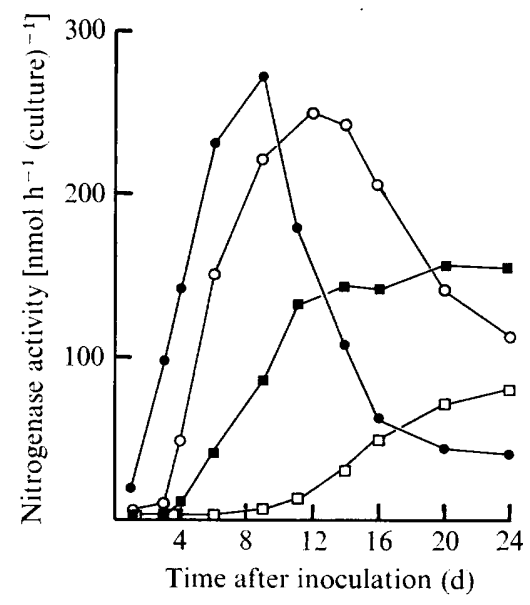

Fig. 2

Fig. 1. Nitrogenase activity $(a, 0)$ and protein content $(\square, \bigcirc)$ of cultures of Rhizobium sp. strain $32 \mathrm{H} 1$ grown on agar in air at $28^{\circ} \mathrm{C}$ from a liquid inoculum $(\square, \square)$ or a soft agar $(0.75 \%)$ inoculum $(0,0)$. Each point is the mean of eight replicates.

Fig. 2. Effect of inoculum density on the nitrogenase activity of Rhizobium sp. strain 32H1 in agar culture. Inocula $\left(0.2 \mathrm{ml}\right.$ of a $0.75 \%$ soft agar suspension) contained (bacteria $\left.\mathrm{ml}^{-1}\right): 0,5 \times 10^{9}$; $0,5 \times 10^{7} ; \square, 5 \times 10^{5} ; \square, 5 \times 10^{3}$. Each point is the mean of eight replicates.

surface of $8 \mathrm{ml}$ of $1.0 \%$ CS8 agar in a McCartney bottle. Maximum rates of nitrogenase activity [50 to $60 \mathrm{nmol} \mathrm{h}^{-1}$ (culture) ${ }^{-1}$ ] developed after 10 to $12 \mathrm{~d}$ incubation at $28^{\circ} \mathrm{C}$ and then declined (Fig. 1). Addition of agar $(0.75 \%)$ to the bacterial broth suspension gave a fivefold increase in nitrogenase activity and a small increase in the total protein content of the cultures over the same period (Fig. 1). Increasing the volume of the inoculum to $2.0 \mathrm{ml}$ or increasing the agar concentration to $1.0 \%$ gave no further increase in nitrogenase activity, but decreasing the agar concentration from 0.75 to $0.25 \%$ caused a decrease in activity.

The number of bacteria in the $0.75 \%$ soft agar inoculum influenced both the rate of development and the maximum nitrogenase activity obtained at $28^{\circ} \mathrm{C}$ (Fig. 2). With a high inoculum density (about $5 \times 10^{9}$ bacteria ml $^{-1}$ ), nitrogenase activity was detectable after $24 \mathrm{~h}$, reached a maximum after $8 \mathrm{~d}$ and then steadily declined. The development of nitrogenase activity was progressively delayed with decreasing inoculum density (Fig. 2).

\section{Morphology in agar culture}

Examination of sections of the soft agar layer of a nitrogen-fixing, 14-d-old culture of strain $32 \mathrm{H} 1$, established with an inoculum density of about $5 \times 10^{7}$ bacteria $\mathrm{ml}^{-1}$, showed that the rhizobia grew in distinct colonies in the agar (Fig. 3a). Differences could be seen in the morphology of the rhizobia in colonies growing at or near the surface, in the middle or at the bottom of the soft agar layer (Figs $3 b, c, d$ ). Three distinct types could be distinguished.

Type 1. These rhizobia grew sparsely in large colonies at or near the surface of the soft agar layer (Fig. $3 b$ ). Within the colonies, the rhizobia were surrounded by large quantities of extracellular polysaccharide (Fig. 3e). This polysaccharide appeared to contain two components: a finely granulated material immediately surrounding the rhizobia, and a detached electron-dense material or slime layer (Cagle, 1975). The rhizobia were rodshaped, and contained large deposits of poly- $\beta$-hydroxybutyrate (PHB), glycogen and polyphosphate (Craig \& Williamson, 1973) (Fig. 4a). They grew more densely and were 

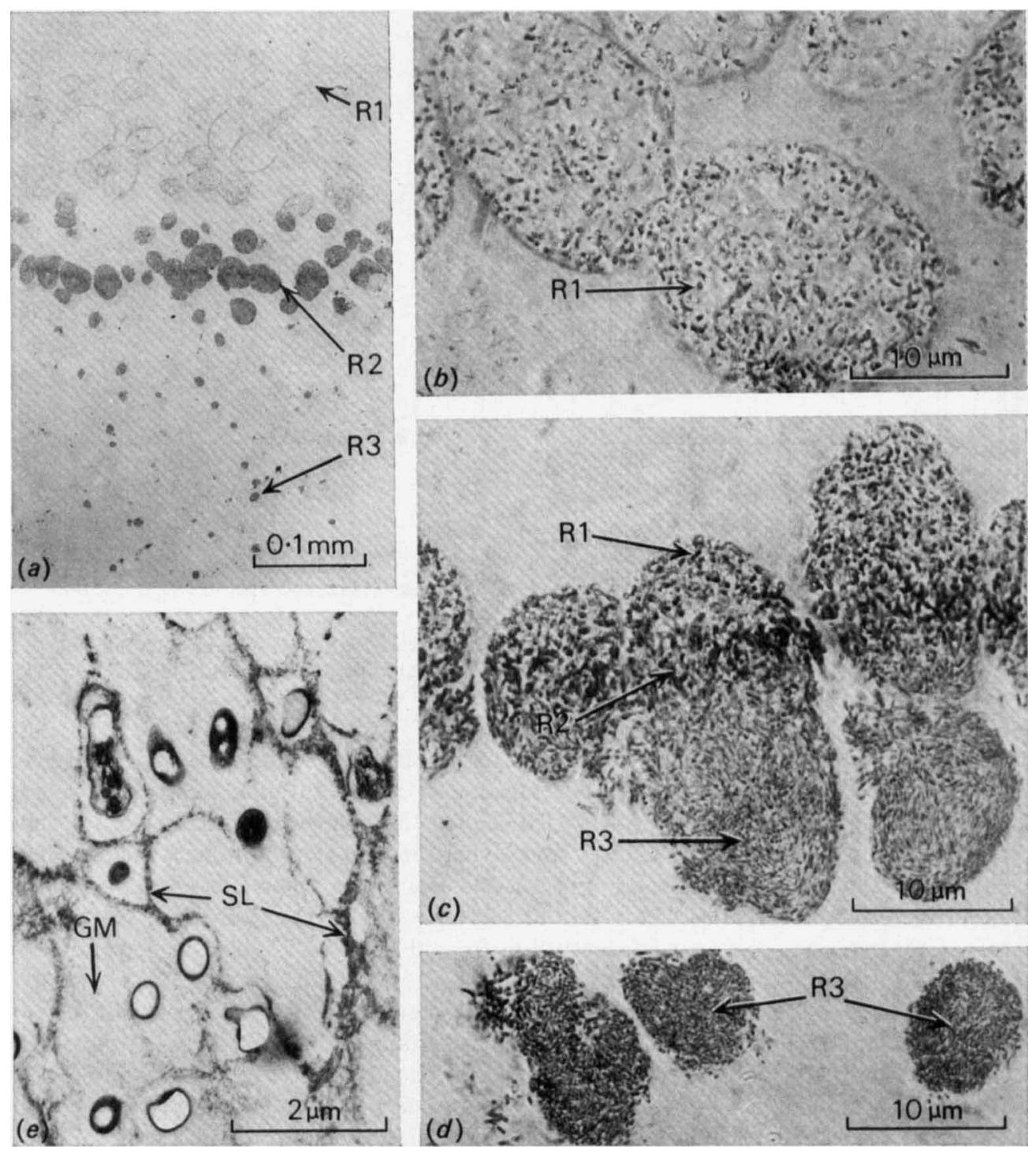

Fig. 3. Sections of a nitrogen-fixing 14-d-old agar culture of Rhizobium sp. strain 32H1. (a) Section through the soft agar layer showing individual colonies containing rhizobia designated as type 1 (R1), type 2 (R2) and type 3 (R3). (b) Colonies containing type 1 Rhizobium (R1) growing near the surface of the soft agar layer. (c) Colonies containing type 1 (R1), type 2 (R2) (present as a band of cells) and type 3 (R3) Rhizobium growing near the middle of the soft agar layer. (d) Colonies containing type 3 Rhizobium(R3) growing near the bottom of the soft agar layer. (e) Part of a colony containing type 1 Rhizobium surrounded by extracellular polysaccharide (stained with Alcian blue). The polysaccharide appears to contain two components: a finely granulated material (GM) immediately surrounding the rhizobia, and a detached electron-dense slime layer (SL).

surrounded by progressively less polysaccharide in colonies (or parts of colonies) growing near the middle of the soft agar layer (Fig. $3 c$ ).

Type 2. These rhizobia were present as a narrow band of bacteria growing at a constant depth in the soft agar; their location within individual colonies therefore varied (Fig. $3 c$ ). They were larger than types 1 or 3 , and were pleiomorphic (Fig. $4 b$ ). They contained small quantities of PHB, glycogen and polyphosphate, and their nuclear material could be easily distinguished (Fig. $4 b$ ). 

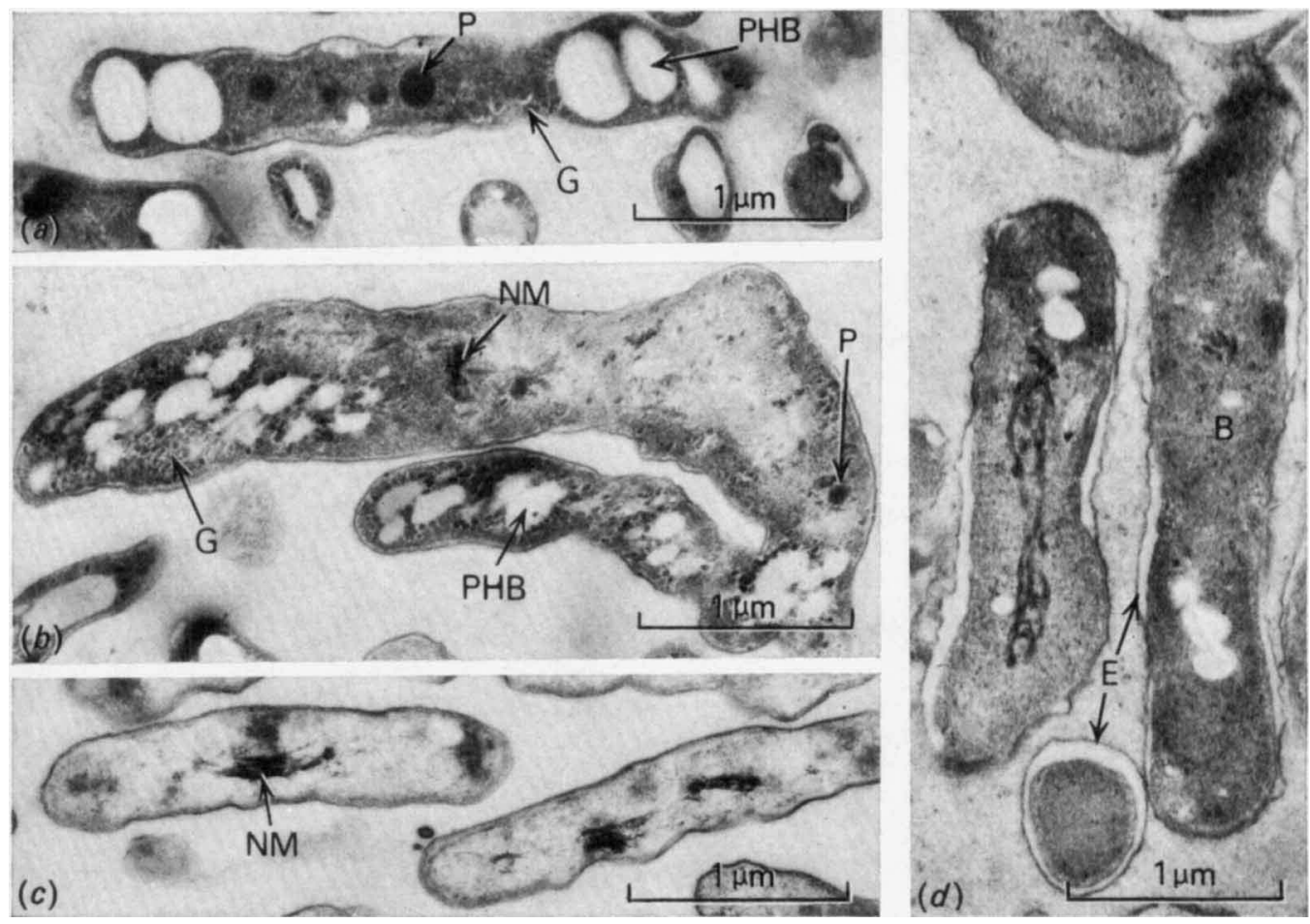

Fig. 4. Electron micrographs of thin sections of different morphological types of Rhizobium sp.strain 32H1. (a) Rod-shaped type 1 Rhizobium containing poly- $\beta$-hydroxybutyrate (PHB), polyphosphate (P) and glycogen (G). (b) Pleiomorphic type 2 Rhizobium containing poly- $\beta$-hydroxybutyrate (PHB), glycogen (G), polyphosphate (P) and clearly defined nuclear material (NM). (c) Rod-shaped type 3 Rhizobium showing less densely stained cytoplasm and prominent nuclear material (NM). $(d)$ Individual bacteroids (B) enclosed by a plant membrane envelope (E) in a 28-d-old cowpea root nodule formed by strain $32 \mathrm{H} 1$.

Type 3. These rhizobia grew in the lower part of colonies containing type 1 and type 2 Rhizobium (Fig. $3 c$ ) and in all colonies formed deeper in the agar (Fig. 3d). The size of these colonies declined markedly towards the bottom of the soft agar layer (Figs $3 a, d$ ). The rhizobia within these colonies were rod-shaped, and contained traces of PHB. However they contained no glycogen or polyphosphate and were not surrounded by extracellular polysaccharide (Fig. $4 c$ ). Their nuclear material was very pronounced.

Comparison of the morphologies of these three types of Rhizobium with the morphology of strain $32 \mathrm{H} 1$ bacteroids grown in a mature (28-d-old) cowpea nodule (Fig. $4 d$ ), indicated that type 2 Rhizobium resembled the bacteroids (compare Figs $4 d$ and $b$ ), although the former were more pleiomorphic. In contrast, the morphologies of type 1 and type 3 Rhizobium were quite different from that of the bacteroids.

Sections of older (21- and 28-d-old) free-living cultures showed similar morphological differences between types 1, 2 and 3 Rhizobium. However, the number of type 1 and type 3 Rhizobium growing in the immediate vicinity of type 2 Rhizobium increased with the age of the culture.

\section{Presence of an oxygen gradient across the soft agar layer}

The change in morphology of strain 32H1 from the top to the bottom of the soft agar layer was believed to be associated with the development of an $\mathrm{O}_{2}$ gradient through the agar. The existence of such a gradient was confirmed by observing the reduction of a redox indicator dye [resazurin, $E_{0}^{\prime}(\mathrm{pH} \mathrm{7.0)}=-42 \mathrm{mV}$; Twigg (1945)] incorporated into the agar. After $10 \mathrm{~d}$ growth at $28{ }^{\circ} \mathrm{C}$ under air, reduction of the resazurin $(0.005 \%, \mathrm{w} / \mathrm{v})$ in the 

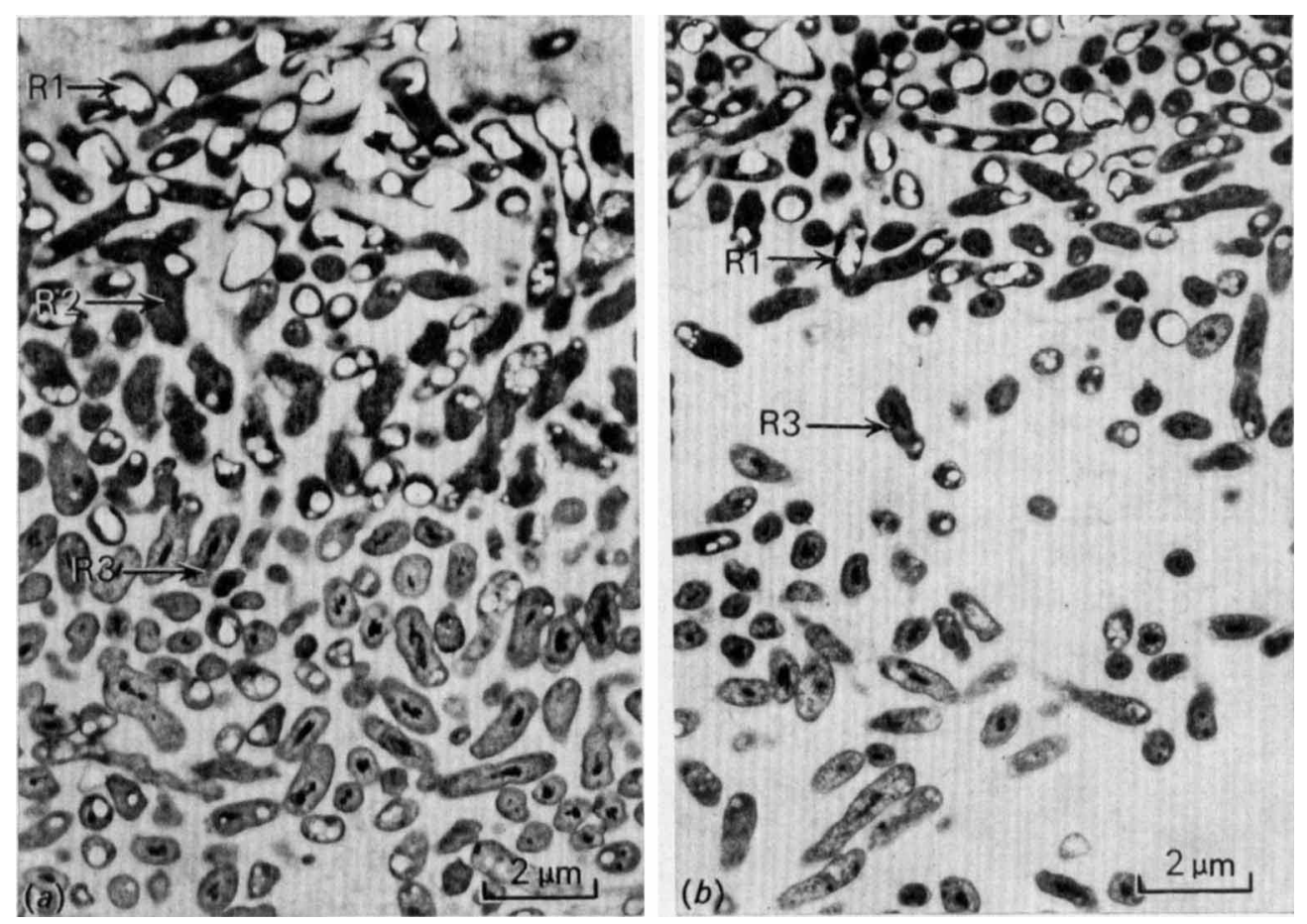

Fig. 5. Sections of 10-d-old agar cultures of Rhizobium sp. strain 32H1 grown in air or $\mathrm{O}_{2} / \mathrm{Ar}(1: 4$, $\mathrm{v} / \mathrm{v}$ ). (a) Part of a colony containing type 1 (R1), type 2 (R2) and type 3 (R3) Rhizobium, grown in air. (b) Part of a colony containing type 1 (R1) and type 3 (R3) (but no type 2) Rhizobium, grown under $\mathrm{O}_{2} / \mathrm{Ar}$.

basal agar was complete, indicating that the $\mathrm{O}_{2}$ present initially in this medium had been utilized by the rhizobia. A decrease in $\mathrm{O}_{2}$ concentration from atmospheric above the soft agar layer to zero below the soft agar layer therefore existed. The decolorized resazurin was reoxidized if the basal agar bearing the culture was subsequently stirred.

\section{Growth in an $\mathrm{O}_{2} / \mathrm{Ar}$ atmosphere}

The morphology of type 2 Rhizobium was similar to that of the nitrogen-fixing bacteroids in cowpea nodules. It was therefore important to establish if it was these rhizobia in the agar culture that possessed nitrogenase. It was of interest to see if these rhizobia were present in agar cultures grown in an $\mathrm{O}_{2} / \mathrm{Ar}(1: 4, \mathrm{v} / \mathrm{v})$ atmosphere. Cultures grown for $14 \mathrm{~d}$ in $\mathrm{O}_{2} / \mathrm{Ar}$ produced less protein and had lower nitrogenase activity $\left[4.3 \mathrm{nmol} \mathrm{h} \mathrm{h}^{-1}(\mathrm{mg}\right.$ protein $\left.)^{-1}\right]$ than cultures grown in air $\left[85.7 \mathrm{nmol} \mathrm{h}^{-1}(\mathrm{mg} \text { protein })^{-1}\right]$. However they did not contain the band of type 2 Rhizobium. Instead a gradual transition from type 1 to type 3 was observed (compare Figs $5 a$ and $b$ ).

\section{Growth in different $\mathrm{O}_{2} / \mathrm{N}_{2}$ atmospheres}

As nitrogenase is readily inactivated by $\mathrm{O}_{2}$ (Bergersen \& Turner, 1968), the morphology and nitrogenase activity of agar cultures grown in atmospheres $\left(\mathrm{O}_{2} / \mathrm{N}_{2}\right)$ containing different $\mathrm{O}_{2}$ concentrations was investigated. The location of the band of type 2 Rhizobium within the soft agar layer varied with the $\mathrm{O}_{2}$ concentration above the agar (Fig. 6). Its distance from the agar surface (measurements made from light micrographs of thick sections of these cultures) was proportional to the logarithm of the $\mathrm{O}_{2}$ concentration from 0.05 to $0.4 \mathrm{~atm}$ $\mathrm{O}_{2}$ (Fig. 7). The nitrogenase activity of these cultures was maximal at the $\mathrm{O}_{2}$ concentration of growth (Fig. 8) but the activities of cultures grown at 0.05 or 0.1 atm $\mathrm{O}_{2}$ were significantly 

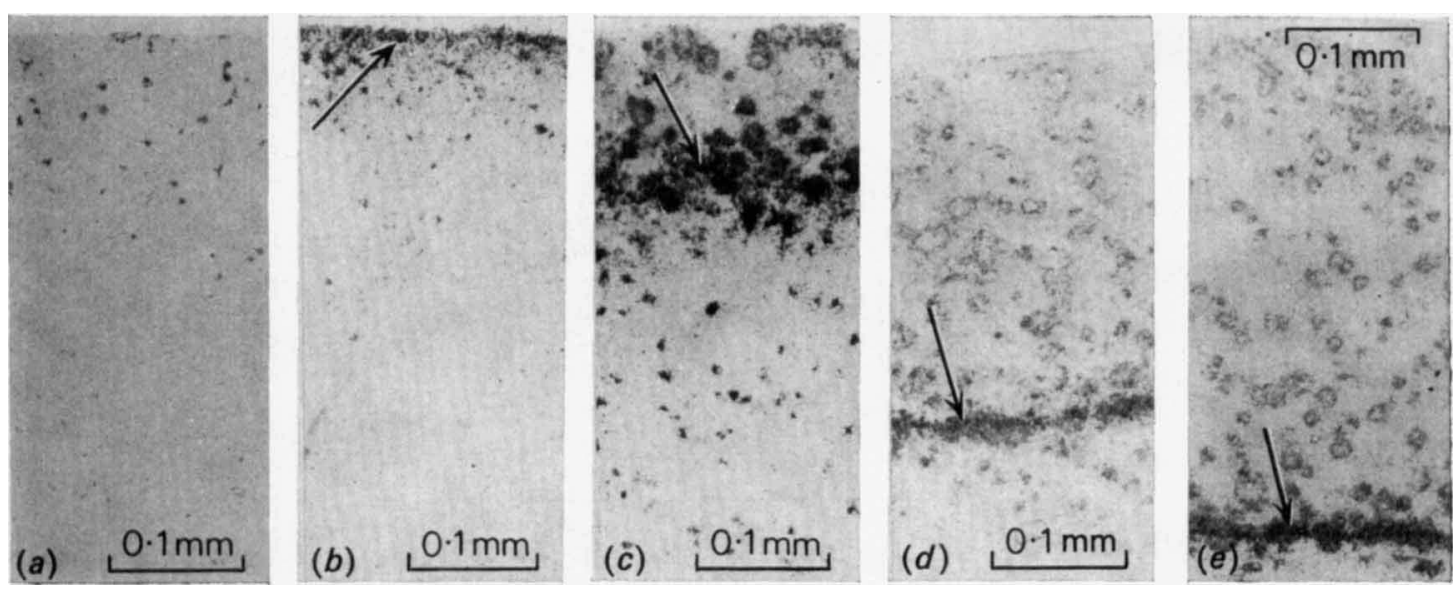

Fig. 6. Sections of 10-d-old agar cultures of Rhizobium sp. strain $32 \mathrm{H} 1$ grown under $\mathrm{O}_{2} / \mathrm{N}_{2}$ atmospheres containing different $\mathrm{O}_{2}$ concentrations $\left(\right.$ atm $\left.\mathrm{O}_{2}\right):(a) 0 ;(b) 0.01 ;(c) 0 \cdot 1 ;(d) 0 \cdot 2 ;(e) 0 \cdot 4$. Note the location of colonies containing type 2 Rhizobium, indicated by arrows.

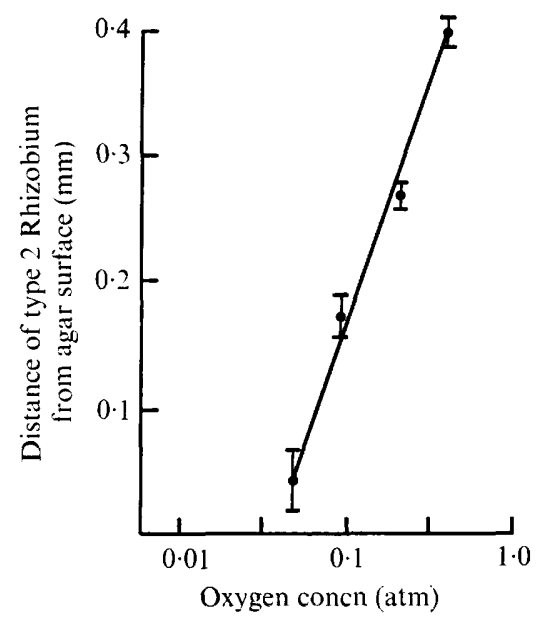

Fig. 7

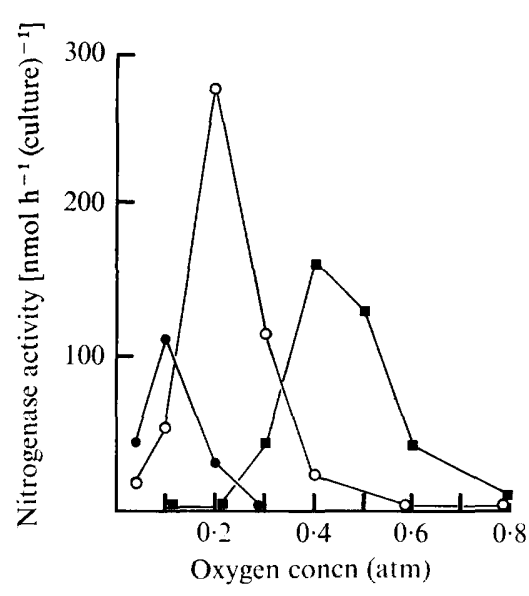

Fig. 8

Fig. 7. Relationship between the location of type 2 Rhizobium in 10-d-old agar cultures of Rhizobium sp. strain $32 \mathrm{H} 1$ and the logarithm of the $\mathrm{O}_{2}$ concentration in the atmosphere above the cultures during growth. Each point is the mean ( \pm S.E.M.) of six measurements from three cultures.

Fig. 8. Effect of $\mathrm{O}_{2}$ concentration in the gas mixture during the acetylene reduction assay for nitrogenase activity in cultures of Rhizobium sp. strain $32 \mathrm{H} 1$ grown for $10 \mathrm{~d}$ under $\mathrm{O}_{2} / \mathrm{N}_{2}$ atmospheres containing different $\mathrm{O}_{2}$ concentrations $\left(\operatorname{atm~} \mathrm{O}_{2}\right.$ ):, $0.1 ; 0,0.2 ; \mathbf{\square}, 0.4$. Each point is the mean of four replicates.

lower than those of cultures grown at 0.2 or $0.4 \mathrm{~atm} \mathrm{O}_{2}$. Cultures grown under atmospheres containing $<0.05$ atm $\mathrm{O}_{2}$ produced only a small amount of growth, comprised mostly of type 3 Rhizobium, at the surface of the soft agar layer. The nitrogenase activity of these cultures was very low ( 1 to $2 \%$ of that of cultures grown under 0.2 atm $\mathrm{O}_{2}$ ).

\section{Effect of temperature}

The appearance of nitrogenase activity was delayed in rhizobia grown at $23{ }^{\circ} \mathrm{C}$, and the maximum activity was significantly lower than at $28^{\circ} \mathrm{C}$ (Fig. 9). Growth at $33^{\circ} \mathrm{C}$ promoted a low level of activity after 4 to $6 \mathrm{~d}$ which then rapidly declined (Fig. 9). The morphology of 


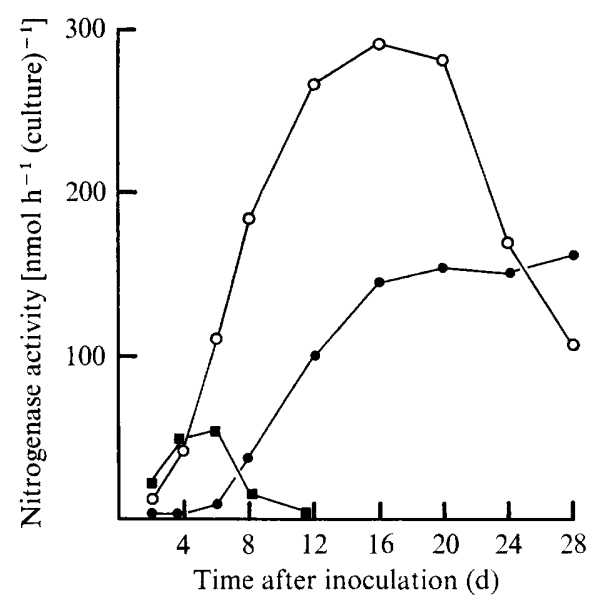

Fig. 9. Effect of temperature on the development of nitrogenase activity by Rhizobium sp. strain $32 \mathrm{H} 1$ in agar culture: $0,23^{\circ} \mathrm{C} ; \mathrm{O}, 28^{\circ} \mathrm{C} ; \mathrm{a}, 33^{\circ} \mathrm{C}$. Each point is the mean of eight replicates.

cultures grown at $23{ }^{\circ} \mathrm{C}$ was similar to those grown at $28^{\circ} \mathrm{C}$ except that the band of type 2 Rhizobium was indistinct until after $14 \mathrm{~d}$ growth. The morphology of cultures grown at $33{ }^{\circ} \mathrm{C}$, however, was different (Fig. $10 \mathrm{a}$ ). In particular, growth of the type $1 \mathrm{Rhizobium}$ in colonies near the surface of the soft agar layer was markedly decreased. Large numbers of small vesicles, whose outer surface reacted strongly with the Alcian blue stain for polysaccharide, were found within these colonies (Fig. 10b). These vesicles appeared to be produced by degenerating rhizobia. Large and variously shaped structures, thought to be remnants of these degenerating rhizobia, were also observed. Other rhizobia had large deposits of Alcian blue positive material on their outer surface (Fig. 10d). The band of type 2 Rhizobium was not observed in these cultures although colonies towards the middle of the soft agar layer did contain a few type 2 Rhizobium; but after $14 \mathrm{~d}$ growth these appeared to be degenerate (Fig. 10c).

\section{Effect of combined nitrogen}

The concentration of three nitrogen sources [glutamine, $\left(\mathrm{NH}_{4}\right)_{2} \mathrm{SO}_{4}$ and $\mathrm{KNO}_{3}$ ] influenced the growth and nitrogenase activity of strain $32 \mathrm{H} 1$ in agar culture (Table 1 ). When supplied with 2 or $4 \mathrm{~mm}-\mathrm{N}$, rhizobia grew equally well on all three nitrogen sources, but at 10 and $20 \mathrm{~mm}-\mathrm{N}$ growth was superior on glutamine. At $2 \mathrm{mM}-\mathrm{N}$, glutamine and $\mathrm{NH}_{4}{ }^{+}$supported similar high levels of nitrogenase activity, but $\mathrm{NO}_{3}{ }^{-}$supported only very low activity. At $20 \mathrm{mM}-\mathrm{N}$, both $\mathrm{NH}_{4}{ }^{+}$and $\mathrm{NO}_{3}{ }^{-}$inhibited nitrogenase activity in contrast to glutamine which still supported significant activity.

Sections of 14-d-old cultures grown on each of the three nitrogen sources at 2 and $20 \mathrm{~mm}-\mathrm{N}$ were examined (Table 2). At $2 \mathrm{~mm}-\mathrm{N}$, the morphology of cultures grown on glutamine and $\mathrm{NH}_{4}{ }^{+}$appeared identical. In contrast, about $90 \%$ of the rhizobia in cultures grown on $2 \mathrm{~mm}^{-\mathrm{NO}_{3}}{ }^{-}$were type 1 and only at the very bottom of the soft agar layer were any type 2 or type 3 Rhizobium observed. At $20 \mathrm{~mm}-\mathrm{N}$, there were marked differences in the morphology of the cultures grown on each nitrogen source (Figs $11 a, b, c$ ). In all three cultures the band of type 2 Rhizobium was absent (Table 2).

The stimulation of growth by glutamine ( $20 \mathrm{~mm}-\mathrm{N})$ (Table 1$)$ was seen in sections of these cultures as a large increase in growth near the surface of the soft agar layer (Fig. 11a). These rhizobia appeared to be a mixture of elongated type 1 and type 2 (Fig. $11 d$ ). Cultures grown on $20 \mathrm{~mm}-\mathrm{NH}_{4}{ }^{+}$or $\mathrm{NO}_{3}{ }^{-}$did not show the same large increase in growth near the soft agar surface; instead dense growth of rhizobia within individual colonies was observed (Figs $11 b, c$ ). These colonies were large and near the surface of the soft agar layer in the 

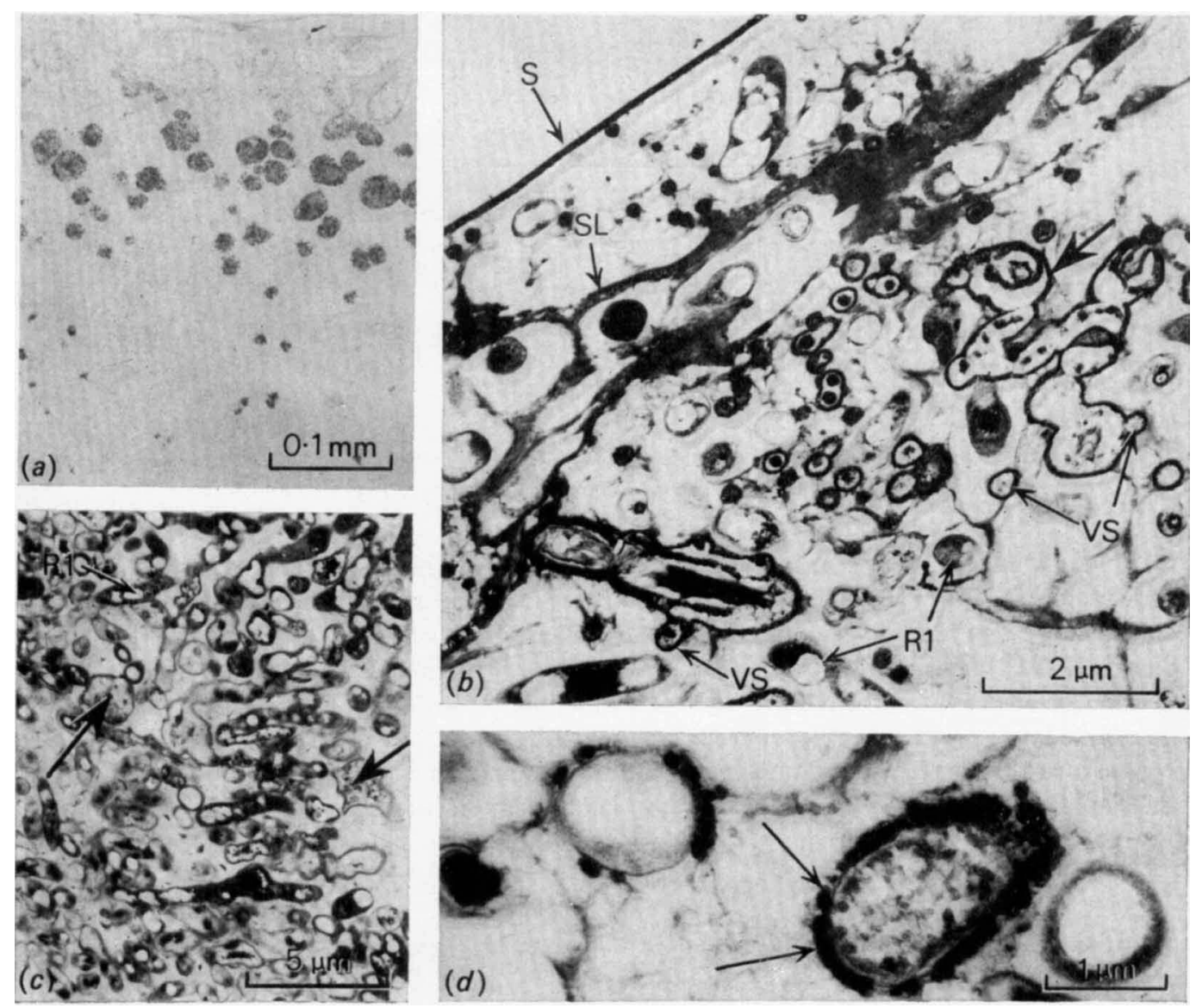

Fig. 10. Sections of a 14-d-old agar culture of Rhizobium sp. strain $32 \mathrm{H} 1$ grown at $33^{\circ} \mathrm{C}$. (a) Section through the soft agar layer showing reduced growth of colonies containing type 1 Rhizobium and absence of a band of pleiomorphic type 2 Rhizobium (cf. Figs $3 a, 6 d$ ). (b) Part of a colony (stained with Alcian blue) near the soft agar surface (S) containing type 1 Rhizobium (R1) surrounded by an electron-dense slime layer (SL) (cf. Fig. $3 e$ ). Many small vesicles (VS) produced by rhizobia undergoing degeneration can be seen. Large and variously shaped structures thought to be remnants of these degenerating rhizobia are also present (large arrow). (c) Part of a colony located in the middle of the soft agar layer showing type 1 Rhizobium (R1) and degenerating type 2 Rhizobium (arrows). (d) Type 1 Rhizobium with deposits of Alcian blue positive material (arrows) on its outer surface.

Table 1. Effect of glutamine, $\mathrm{NH}_{4}^{+}$and $\mathrm{NO}_{3}{ }^{-}$concentration on the nitrogenase activity of 32H1 in agar culture after 14 growth

Protein contents are expressed as $\mathrm{mg}$ (culture) $^{-1}$, and nitrogenase activities as nmol acetylene reduced h$h^{-1}(\mathrm{mg} \text { protein })^{-1}$. Values are the average of six replicates. $\mathrm{NH}_{4}{ }^{+}$was added as $\left(\mathrm{NH}_{4}\right)_{2} \mathrm{SO}_{4}$ and $\mathrm{NO}_{3}{ }^{-}$as $\mathrm{KNO}_{3}$.

\begin{tabular}{|c|c|c|c|c|c|c|}
\hline \multirow[b]{2}{*}{ Concn $(\mathrm{mm}-\mathrm{N})$} & \multicolumn{2}{|c|}{ Glutamine } & \multicolumn{2}{|c|}{$\mathrm{NH}_{4}{ }^{+}$} & \multicolumn{2}{|c|}{$\mathrm{NO}_{3}^{-}$} \\
\hline & $\begin{array}{l}\text { Protein } \\
\text { content }\end{array}$ & $\begin{array}{c}\text { Nitrogenase } \\
\text { activity }\end{array}$ & $\begin{array}{l}\text { Protein } \\
\text { content }\end{array}$ & $\begin{array}{l}\text { Nitrogenase } \\
\text { activity }\end{array}$ & $\begin{array}{l}\text { Protein } \\
\text { content }\end{array}$ & $\begin{array}{l}\text { Nitrogenase } \\
\text { activity }\end{array}$ \\
\hline $2 \cdot 0$ & 1.9 & $122 \cdot 1$ & $1 \cdot 7$ & $125 \cdot 8$ & $1 \cdot 8$ & $7 \cdot 3$ \\
\hline $4 \cdot 0$ & $2 \cdot 8$ & $132 \cdot 0$ & $2 \cdot 6$ & $85 \cdot 2$ & $3 \cdot 0$ & 1.5 \\
\hline $10 \cdot 0$ & $5 \cdot 1$ & $30 \cdot 5$ & $3 \cdot 2$ & $11 \cdot 8$ & $3 \cdot 7$ & $0 \cdot 2$ \\
\hline $20 \cdot 0$ & 8.9 & $12 \cdot 3$ & $4 \cdot 1$ & 0.0 & $5 \cdot 3$ & 0.0 \\
\hline
\end{tabular}


Table 2. Summary of morphological types in 14-d-old cultures of $32 \mathrm{H} 1$ grown at $28^{\circ} \mathrm{C}$ in the presence of low or high concentrations of three different combined nitrogen sources

Combined nitrogen source and concn (mM-N)

\begin{tabular}{|c|c|c|c|c|c|c|}
\hline \multirow[b]{2}{*}{ Rhizobium type } & \multicolumn{2}{|c|}{ Glutamine } & \multicolumn{2}{|c|}{$\mathrm{NH}_{4}{ }^{+}$} & \multicolumn{2}{|c|}{$\mathrm{NO}_{3}^{-}$} \\
\hline & 2 & 20 & 2 & 20 & 2 & 20 \\
\hline Type 1 & + & + & + & + & + & - \\
\hline Type 2 & + & + & + & - & + & - \\
\hline $\begin{array}{l}\text { Type } 2 \text { (present as } \\
\text { a distinct band) }\end{array}$ & + & - & + & - & - & - \\
\hline Type 3 & + & + & + & + & + & + \\
\hline Type $4^{*}$ & - & - & - & - & - & + \\
\hline
\end{tabular}

$\mathrm{NH}_{4}{ }^{+}$-grown culture (Fig. $11 \mathrm{~b}$ ), but near the bottom of the soft agar layer in the $\mathrm{NO}_{3}{ }^{-}-$ grown culture (Fig. 11 c). The rhizobia in colonies near the agar surface in the $\mathrm{NH}_{4}{ }^{+}$-grown culture were type 1 and those in colonies near the bottom of the agar layer were type 3 . In contrast, the rhizobia in colonies in the middle and near the surface of the soft agar layer in the $\mathrm{NO}_{3}{ }^{-}$-grown culture were enlarged and pleiomorphic (Fig. 11e). These rhizobia, designated type 4 (Table 2), contained significantly more polyphosphate than the type 2 rhizobia present in the glutamine-grown cultures (compare Figs $11 e$ and $4 b$ ). The rhizobia in colonies near the bottom of the soft agar layer in these cultures were type 3 (Fig. 11f).

\section{DISCUSSION}

Nitrogenase activity in Rhizobium sp. strain $32 \mathrm{H} 1$ has been observed by several workers using different media and culture techniques (Keister, 1975; Pagan et al., 1975; Tjepkema \& Evans, 1975; Bergersen et al., 1976; Scowcroft et al., 1976). In the present work, this strain was grown in a layer of soft agar on top of harder agar. This resulted in the development of significantly higher levels of nitrogenase activity than those obtained by Pagan et al. (1975) and Gibson et al. (1976), who used liquid inocula to establish agar cultures. The highest level of activity recorded [ $430 \mathrm{nmol} \mathrm{h}^{-1}$ (culture) $)^{-1}$ or $\left.142 \mathrm{nmol} \mathrm{h}^{-1}(\mathrm{mg} \text { protein) })^{-1}\right]$ was also three to four times higher than that reported by Scowcroft et al. (1976) and Gibson, Scowcroft \& Pagan (1977) for the same organism grown in soft agar on Millipore filter discs. This may be due to differences in the amount of agar or number of bacteria in the inoculum, since both factors can affect the level of activity.

Because of the low $\mathrm{O}_{2}$ concentration needed for the development of nitrogenase activity (Bergersen et al., 1976; Keister \& Evans, 1976), it has been suggested that, in an agar culture in air, nitrogenase activity is confined to those rhizobia growing in zones of low $\mathrm{O}_{2}$ concentration within the culture (Gibson et al., 1976, 1977; Bergersen et al., 1976). Our examination of sections of the soft agar layer of nitrogen-fixing cultures supports this suggestion. These sections showed that the rhizobia most likely to contain nitrogenase were present as a distinct band of cells passing through individual colonies in the middle of the soft agar layer. Direct evidence for the presence of nitrogenase in these rhizobia is lacking, but the following observations support the view that only these rhizobia in the culture contain nitrogenase. (1) These rhizobia (designated type 2) were the only ones in the culture that resembled bacteroids formed in cowpea root nodules. (2) They were not found in cultures grown under $\mathrm{O}_{2} / \operatorname{Ar}(1: 4, \mathrm{v} / \mathrm{v})$ despite the fact that these cultures developed a low level of nitrogenase activity. Although traces of $\mathrm{N}_{2}$ were present in the Ar used (see Methods), $\mathrm{N}_{2}$ is probably not required for nitrogenase synthesis (cf. Dalton \& Mortenson, 1972). 

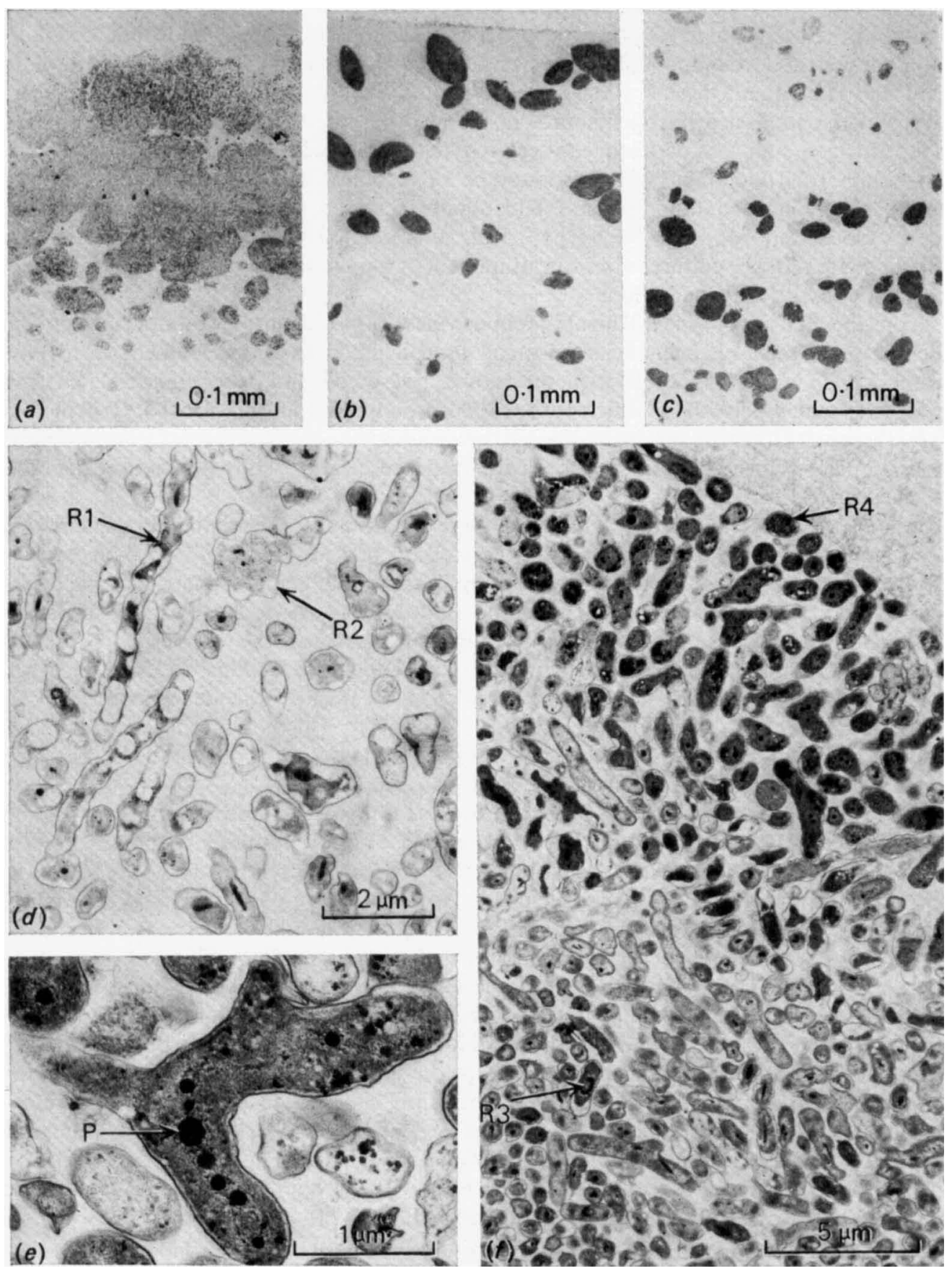

Fig. 11. Sections through the soft agar layer of 14-d-old cultures of Rhizobium sp. strain $32 \mathrm{H} 1$ grown in the presence of three different combined nitrogen sources $(20 \mathrm{mM}-\mathrm{N})$ : (a) glutamine; (b) $\mathrm{NH}_{4}{ }^{+}$; (c) $\mathrm{NO}_{3}^{-}$. (d) Elongated type 1 Rhizobium (R1) and pleiomorphic type 2 Rhizobium (R2) growing near the surface of the soft agar layer in a culture grown on glutamine $(20 \mathrm{mM}-\mathrm{N})$. (e) A pleiomorphic type 4 Rhizobium in a colony growing in the middle of the soft agar layer in a culture grown on $\mathrm{NO}_{3}{ }^{-}(20 \mathrm{~mm})$. Note the prominent polyphosphate bodies $(\mathrm{P})$. $(f)$ Part of a colony growing near the bottom of the soft agar layer in a culture grown on $\mathrm{NO}_{3}-(20 \mathrm{mM})$, showing the transition from the pleiomorphic type 4 Rhizobium (R4) (Fig. 11e) to rod-shaped type 3 Rhizobium (R3). 
(3) The location of these rhizobia within the soft agar layer changed with the $\mathrm{O}_{2}$ concentration in the atmosphere $\left(\mathrm{O}_{2} / \mathrm{N}_{2}\right)$ above the agar during growth. (4) Growth at $33{ }^{\circ} \mathrm{C}$ led to only transient development of nitrogenase activity which was correlated with the development and subsequent degeneration of the type 2 Rhizobium. (5) The concentration and nature of the combined nitrogen source in the medium affected the ability of strain $32 \mathrm{H} 1$ to fix nitrogen, and loss of nitrogenase activity correlated with loss of the band of type 2 Rhizobium. (6) The number of type 1 and type 3 Rhizobium in colonies immediately above and below colonies containing type 2 Rhizobium increased as the cultures aged, possibly due to the excretion of $\mathrm{NH}_{4}+$ by type 2 Rhizobium. The slow continued increase in the protein content of the cultures after the attainment of maximum nitrogenase activity (Fig. 1) is consistent with this suggestion.

From the number of type 2 Rhizobium in a typical 14-d-old culture (estimated from light micrographs), their nitrogenase activity can be calculated as 900 to $1000 \mathrm{nmol} \mathrm{h}^{-1}$ (mg protein $)^{-1}$. This is comparable with the nitrogenase activity of bacteroids isolated from nodules (Kennedy, 1970) in which rates between 300 and $1500 \mathrm{nmol} \mathrm{h}^{-1}(\mathrm{mg} \text { protein) })^{-1}$ were observed. It is also similar to the nitrogenase activity of $700 \mathrm{nmol} \mathrm{h}^{-1}$ (mg protein)-1 in strain $32 \mathrm{H} 1$ grown in liquid culture in the presence of a low concentration of dissolved $\mathrm{O}_{2}$ (Keister \& Evans, 1976).

Perhaps the most interesting feature of these putative nitrogen-fixing rhizobia is their development at a constant depth within the soft agar layer. The rate of $\mathrm{O}_{2}$ consumption by the culture coupled with the presence of a small amount of combined nitrogen and a large amount of carbohydrate in the culture medium (Gibson et al., 1976) are probably key factors associated with this. As production of extracellular polysaccharide by bacteria is stimulated by aerobic growth in media with a high $\mathrm{C}: \mathrm{N}$ ratio (Duguid \& Wilkinson, 1953), the extracellular polysaccharide produced by the type 1 Rhizobium near the soft agar surface may be important for the development of nitrogenase activity. This polysaccharide may reduce the rate of $\mathrm{O}_{2}$ diffusion into the culture (Postgate, 1971) and thus encourage development of the band of type 2 Rhizobium.

Increasing the $\mathrm{O}_{2}$ concentration in the atmosphere above the culture (from 0.2 to $0.4 \mathrm{~atm}$ ) would increase the number of type 1 Rhizobium in the culture resulting in the development of the band of type 2 Rhizobium deeper in the agar (Fig. 6). Decreasing the $\mathrm{O}_{2}$ concentration (to $<0.2 \mathrm{~atm}$ ) would have the opposite effect. However, because less $\mathrm{O}_{2}$ would be available the number of bacteria receiving sufficient $\mathrm{O}_{2}$ for growth would be decreased. This could lead to slower utilization of the combined nitrogen in the medium which, in turn, could explain why these cultures developed only low levels of nitrogenase activity.

Increasing the incubation temperature or increasing the concentration of the combined nitrogen source in the medium decreased or inhibited the development of nitrogenase activity. Increasing the temperature appeared to disrupt the development of type 2 Rhizobium and to promote the degeneration of type 1 Rhizobium. This is analogous to the disruption of bacteroid development and the degeneration of vegetative Rhizobium in clover root nodules at high root temperature (Pankhurst \& Gibson, 1973). Increasing the nitrogen content of the medium appeared to repress nitrogenase activity by stimulating the growth of the rhizobia. The growth of rhizobia in the presence of $\mathrm{NO}_{3}{ }^{-}$towards the bottom of the soft agar layer (in contrast to growth near the surface with glutamine or $\mathrm{NH}_{4}{ }^{+}$) may be associated with the ability of $\mathrm{NO}_{3}{ }^{-}$to substitute for $\mathrm{O}_{2}$ as an electron acceptor and thus promote anaerobic growth (Daniel \& Appleby, 1972).

We wish to thank Miss P. A. Mundt for skilled technical assistance, Mr I. D. Simpson for help in the preparation of the photographs and Mr K. I. Williamson for helpful discussions during the preparation of the manuscript. 


\section{REFERENCES}

BeHNKe, O. \& Zelander, T. (1970). Preservation of intercellular substances by the cationic dye Alcian blue in preparative procedures for electron microscopy. Journal of Ultrastructure Research 31, 424-438.

Bergersen, F. J. \& Turner, G. L. (1968). Comparative studies of nitrogen fixation by soybean root nodules, bacteroid suspensions and cell-free extracts. Journal of General Microbiology 53, 205-220.

Bergersen, F. J., Turner, G. L., Gibson, A. H. \& Dudman, W. F. (1976). Nitrogenase activity and respiration of cultures of Rhizobium spp. with special reference to concentration of dissolved oxygen. Biochimica et biophysica acta 444, 164 174.

CAGLE, G. D. (1975). Fine structure and distribution of extracellular polymer surrounding selected aerobic bacteria. Canadian Journal of Microbiology 21, 395-408.

Craig, A.S. \& Williamson, K. I. (1973). Three inclusions of rhizobia bacteroids and their cytochemical character. Archiv für Mikrobiologie 87, 165-171.

Dalton, H. \& Mortenson, L. E. (1972). Dinitrogen $\left(\mathbf{N}_{2}\right)$ fixation (with a biochemical emphasis). Bacteriological Reviews 36, 231-260.

DANiel, R. M. \& APPleBy, C. A. (1972). Anaerobicnitrate, symbiotic and aerobic growth of Rhizobium japonicum: effects on cytochrome $P_{450}$, other haemoproteins, nitrate and nitrite reductases. Biochimica et biophysica acta 275, 347-354.

Duguid, J. P. \& Wilkinson, J. F. (1953). The influence of cultural conditions on polysaccharide production by Aerobacter aerogenes. Journal of General Microbiology 9, 174-189.

Evans, W. R. \& KeISTER, D. L. (1976). Reduction of acetylene by stationary cultures of free-living Rhizobium sp. under atmospheric oxygen levels. Canadian Journal of Microbiology 22, 949-952.

Gibson, A. H., ScowcrofT, W. R., ChILd, J. J. \& PAGAN, J. D. (1976). Nitrogenase activity in cultured Rhizobium sp. strain $32 \mathrm{H} 1$ : nutritional and physical considerations. Archives of Microbiology 108, 45-54.

Gibson, A. H., Scowcrofr, W. R. \& Pagan, J. D. (1977). Nitrogen fixation in plants: an expanding horizon? In Recent Developments in Nitrogen Fixation, pp. 387-417. Edited by W. E. Newton, J. R. Postgate \& C. Rodriguez-Barrueco. London $\&$ New York: Academic Press.

Hardy, R. W. F., Holsten, R. D., Jackson, E. K.
\& BURNS, R. C. (1968). The acetylene-ethylene assay for $\mathrm{N}_{2}$ fixation: laboratory and field evaluation. Plant Physiology 43, 1185-1207.

KeISTER, D. L. (1975). Acetylene reduction by pure cultures of rhizobia. Journal of Bacteriology 123, 1265-1268.

Keister, D. L. \& Evans, W. R. (1976). Oxygen requirement for acetylene reduction by pure cultures of rhizobia. Journal of Bacteriology 129, 149-153.

KENNEDY, I. R. (1970). Kinetics of acetylene and $\mathrm{CN}^{-}$reduction by the $\mathrm{N}_{2}$-fixing system of Rhizobium lupini. Biochimica et biophysica acta 222, 135-144.

KuRz, W. G. W. \& LA RuE, T. A. (1975). Nitrogenase activity in rhizobia in absence of plant host. Nature, London 256, 407-408.

Lowry, O. H., Rosebrough, N. J., Farr, A. L. \& RANDALL, R. J. (1951). Protein measurement with the Folin phenol reagent. Journal of Biological Chemistry 193, 265-275.

МсСомв, J. A., Elliotт, J. \& Dilworth, M. J. (1975). Acetylene reduction by Rhizobium in pure culture. Nature, London 256, 409-410.

PaGan, J. D., ChIld, J. J., Scowcroft, W. R. \& Gibson, A. H. (1975). Nitrogen fixation by Rhizobium cultured on a defined medium. Nature, London 256, 406-407.

PankHurst, C. E. (1977). Symbiotic effectiveness of antibiotic-resistant mutants of fast and slowgrowing strains of Rhizobium nodulating Lotus species. Canadian Journal of Microbiology 23, 1026-1033.

Pankhurst, C. E. \& Gibson, A. H. (1973). Rhizobium strain influence on disruption of clover nodule development at high root temperature. Journal of General Microbiology 74, 219-231.

Postgate, J. R. (1971). Fixation by free-living microbes: physiology. In The Chemistry and Biochemistry of Nitrogen Fixation, pp. 161-190. Edited by J. R. Postgate, London: Plenum Press. Scowcroft, W. R., Gibson, A. H. \& Pagan, J. D. (1976). Nitrogen fixation in cultured cowpea rhizobia: inhibition and regulation of nitrogenase activity. Biochemical and Biophysical Research Communications 73, 516-523.

TJEPKEMA, J. D. \& EvaNS, H. J. (1975). Nitrogen fixation by free living Rhizobium in a defined liquid medium. Biochemical and Biophysical Research Communications 65, 625-628.

TwIGG, R. S. (1945). Oxidation-reduction aspects of resazurin. Nature, London 155, 401-402. 